\title{
Flouting the Gricean Maxims in Satire
}

\author{
Maisoun Abu -Joudeh, Jameleh Fanoun \\ Department of English Language and Literature \\ The Hashemite University, Zarqa \\ Jordan
}

\begin{abstract}
The main thrust of this study was to find out the conversational implicatures generated from flouting the Gricean maxims in two Jordanian satirical plays, namely "Muatin hasb alttalab" (1997) and "Al'an fahumtukum" (2012). Sixty-six talk exchanges from the two plays were analyzed to identify instances of flouting the Gricean maxims (quantity, quality, relation, and manner). The findings revealed that both plays flouted the Gricean maxims to poke fun and laughter. Furthermore, the maxims of quality and relation were flouted the most by the characters of both plays to ensure that their message is delivered effectively. Moreover, it was found that the characters of "al'an fahumtukum" had more space and freedom to express themselves than those in "muatin hasb alttalab" since the former was written in an era characterized by a democratic spirit.
\end{abstract}

Keywords: conversational maxims; flouting of Grice's maxims; implicature; satire

\section{Introduction and Aims}

When we talk, we assume, even without realizing it, that we and the people we are talking to need to be conversationally cooperative. Grice (1975) posited a set of general rules that contributors to ordinary conversation are generally expected to follow. He named it the Cooperative Principle and fleshed it out in four conversational maxims. He suggests that interlocutors must adhere to these maxims in order to understand each other and be able to get their points across. The underlying assumption underpinning the cooperative principle as a main driving force in communication is that participants in a conversation normally try to be informative, truthful, relevant and clear. However, people undoubtedly can be tight-lipped, untruthful, off-topic or even ambiguous. In this case, they are said to flout these four conversational maxims that fleshed out the cooperative principle in order to imply a meaning implicitly. The present study analyzed sixty-six talk exchanges taken from two Jordanian satirical plays "Muatin Hasb Alttalab" (1997) and "Al'an Fahumtukum" (2012) in an attempt to explore how the characters of these plays flout the maxims to provoke fun as well as criticize government. It aimed to examine each and every instance of flouting in both of the plays to figure out the possible effects of using these flouts.

\section{Research Questions}

Based on the objectives, the following questions were addressed:

i. What conversational maxims are flouted, and which ones are flouted most in both plays?

ii. What are the possible functions these flouts perform in the two plays?

\section{Theoretical Framework}

\subsection{Implicature}

Grice (1969) has an influential role in the field of pragmatics through proposing the notion implicature and developing the cooperative principle theory later on. Grice's theory is an attempt to explain how the addressee gets from literal words what is meant; that is from the level of expressed meaning to the level of intended meaning. "The word 'implicates' denotes the action of suggesting information as opposed to stating information explicitly" (Archer, et al., 2012, p.47). Implicit is the preferred way of defining this process in pragmatics. "Grice's essential definition sought to capture the central role played by the speaker $(S)$ in conveying to hearer's (H) information that isn't stated" (Ibid, p. 47). 
Grice (1975) argues that hearers generate an implicature by drawing on "the conventional meanings of words, the cooperative principle and its maxims, the linguistic and non-linguistic context of the utterance, items of background knowledge and the fact that all of these are available to both participants and they both assume this to be the case" (Paltridge 2012, p.51). The following example illustrates this:

A: How are we getting to the airport tomorrow?

B: Well ... I'm going with Peter.

Here, $\mathrm{B}$ flouts the maxim of quantity by giving less information than is required and the hearer has to infer that he or she may have to make their own way to the airport.

\subsection{The Cooperative principle}

Grice (1975) states “Our talk exchanges don't normally consist of a succession of disconnected remarks. They are cooperative efforts; and each participant recognizes his ther purpose, or at least a mutually accepted direction of the conversation" (p. 44). In order to have a smooth conversation, there are certain social conventions that need to be observed in all verbal exchanges. Based on this assumption, Grice put forward four conversational maxims that underpin the theory of the cooperative principle. This theory aims to establish clear, precise, informative and true conversations. Thomas (1995) maintains that the main underlying assumption of the cooperative principle is that people cooperate when they are conversing (p. 62).

\subsubsection{The conversational maxims}

Grice (1975) suggested four conversational maxims to organize a well-constructed, successful and clear conversation process:

1) Quantity: A- Make your contribution as informative as required.

B- Don't say more than it is required.

2) Quality: Be truthful. A- Don't say what you believe to be false.

B- Don't say that for which you lack evidence.

3) Relation: Be relevant.

4) Manner: Be perspicuous.

A- Avoid obscurity of expression.

B- Avoid ambiguity.

C- Be brief.

D- Be orderly. (p. 46).

Grice was not trying to tell us how to behave as interlocutors. He was suggesting that:

1) Conversation is governed by certain conventions.

2) Hearers tend to assume speakers are conforming to these conventions.

3) If speakers aren't conforming, then they have a good reason not to (Archer, et al., 2012, p.52).

\subsection{Non-observance of Grice's Maxims}

Though observance of maxims generally leads to successful conversation, speakers may opt to manipulate the social conventions of language use to create specific modifications by flouting these maxims, that is, prudently infringing, ignoring, subverting or opting out of a maxim for a particular effect (Thomas 2006). Grice (1975) identified flouting as, "whereby S deliberately fails to observe a maxim or maxims as a mean of prompting others to look for a meaning which is different from, or in addition to, the expressed meaning" (p. 42). A maxim is thus flouted when the speaker feels that observing the usual conventions, or maxims, will not be as effective (Rost 2013, p. 84-85):

- By flouting the maxim of quantity, the speaker may prevent an interlocutor from getting the floor and presenting information that may contradict the speaker's assertions or intentions.

- By flouting the maxim of quality, the speaker may gain the perception of authority without needing to provide adequate evidence for assertions.

- By flouting the maxim of relevance, the speaker may derail the interlocutor's intentions.

- By flouting the maxim of manner and creating ambiguity, the speaker may later exploit this ambiguity and turn it into a desired result. 
Whenever a conversation unfolds, a listener will be to infer the speaker's intention and will be able to arrive at a particular effect. In other words, he will be able to derive an implicature. The present study focuses on flouts of the maxims as one way of non-observing the maxims.

\subsection{Satire}

Writers use satire as a technique to censure the merits and faults of an individual or a society by using humor, irony, exaggeration and ridicule. It is used in many works of literature to effect social or political change. The present study examined how Jordanian satirists flout the Gricean maxims to shame governments into improvement and to warn society against corruption.

\section{Methodology}

\subsection{Data Collection}

Two four-hour long Jordanian satirical plays were chosen to be analyzed in this study. Sixty-six talk exchanges from the two plays were analyzed to identify instances of flouting the Gricean maxims (quantity, quality, relation, and manner). The first twenty-seven examples were taken from "Muatin hasb alttalab" which was written in 1997, a year in which Jordanians protested against soaring food prices. The second thirty-nine examples were taken from "Al'an fahumtukum" which was written in 2012. "Al'an fahumtukum" (2012) derived its title from a phrase that was uttered by the Tunisian deposed President "Zane El-Abidine Ben Ali", when he announced to the Tunisian people that he finally understood them. The main focus of this play is Jordanian government's corruption. A case when a flouting of maxims is used to evoke a specific effect can be seen in the following example:

Context: Suma's friends (political activists) ask for his opinion as a normal citizen about the anti-government protests, and he replies:

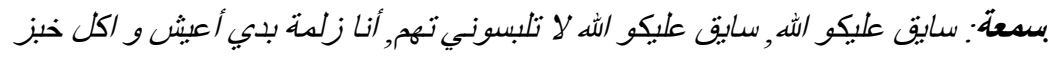

Sum'a: For God's sake, for God's sake. I don't want to get involved in politics. I can barely offer buying bread. أبوثائر: سمعة ما هيّك بتحكي في السباسة!

Abu Tha'er: Sum'a, you are actually talking politics.

سمعة: بقلك بلي : آكل خبز!

Sum'a: I'm telling you that I just want to eat bread!

Abu Tha'er: Bread is the key of politics.

سمعة: هسع الخبز سياسة؛

Sum'a: Is bread politics nowadays?

أبوثائر: الأساس تاع السياسة.

Abu Tha'er: It's the essence of politics.

سمعة: با الله, كيف القرشلة لعاد!

Sum'a: Oh God, What about cookies then!

Here the main character of the play, Sum'a, flouts the relation, manner and quantity maxims. Sum'a's friends ask him to express his opinion about the current situation. Surprisingly, Suma'a replies that he can barely offer buying bread. His response is irrelevant to the topic of the conversation. He also flouts the manner maxim by not being perspicuous. He confuses interlocutors by saying "I can barely offer buying bread". Yet, Jordanians simply get the intended message beyond this implicature; that Sum'a is afraid of the consequences of expressing his opinion. In addition, the rest of his sentence flouts the quantity maxim which states ' make your contribution as informative as required' as he didn't give a sufficient answer to his friend's question. As for the other interlocutor, Abu Tha'er, he flouts the relation and the manner maxims by saying to Sum'a that he is talking politics whilst talking about bread which may seem irrelevant and ambiguous. Yet, by referring to the context of the play, it is well-known by Jordanians in general and by the interlocutors of the implicature in particular that the increase in bread prices is the crucial reason behind the ongoing protest. In other words, "Bread" here is culturally symbolic as most people in Jordan have always relied on bread as a low-cost source of livelihood.

Moreover, Sum'a's answer 'Oh God, what about cookies then!' is irrelevant, but sarcastically makes fun of the increased price of bread, a recurrent issue in Jordan. 


\subsection{Data Analysis}

The study used a descriptive qualitative method to find out the conversational implicatures generated from flouting Grice's maxims in sixty-six talk exchanges to answer the questions of this study which are: what conversational maxims are flouted? Which ones are flouted the most in both of the plays? And what are the possible functions these flouts perform in the two plays? In some instances, there was more than one maxim flouted. For example, some instances flouted the relation, manner and quality maxims as the above example shows. In these cases, the three maxims collaborated to create the intended effect. After investigating each and every instance of flouting, the distribution of flouts was presented, along with their effects.

\section{Previous research}

Several studies have devoted considerable attention to the Cooperative Principle and associated maxims (Leech (1983), Horn (1984), Sperber and Wilson (1995), Bach (1994), Levinson (1995), Davis (2010), among others). Other studies have been conducted to study the Cooperative Principle cross-linguistically and across-cultures. Devine (1982), for example, tested the universality of the conversational maxims and the process of creating implicatures. He provides an assessment of his subjects' ability to understand the given examples of English. He took 15 second-language students and 15 Native-American students as subjects. They were given fifteen situations of conversational implicature examples to read. He used two criteria to assess their responses. First, the subject's comprehension of the intended message. Second, the subject's misunderstanding of the intended message. The findings revealed that the two groups have the same ability of understanding with a slight difference. However, when it comes to the quantity maxim, the data has some problems due to cultural differences which led to different interpretations.

Bouton's cross-sectional study (1988) investigated whether a learner's cultural background can affect his or her ability to derive the same messages from conversational implicatures in English as the native speakers do. Each of the test items consisted of a dailogue involving an implicature that subjects were supposed to interpret and sufficient context to permit them to do so. The results uncovered empirical evidence showing that even reasonably proficient nonnative speakers interpret implicatures differnetly from American native speakers. Bouton thus concluded that cultural background had a great impact on the subjects' ability to interpret implicatues in American English.

Ahmed (2007) is one of few studies that adopted the cooperative principle theory to analyze humorous discourse in Arabic. His study examined the cooperative aspects of humorous discourse as a non-bona-fide mode of communication. After investigating some humorous jokes of Arabic, it was found that the violations of the maxims were mutually dependent. The researcher claimed that when a joke represents a humorous discourse, it will not violate one maxim, but rather other maxims in effect.

Ibrahim (2014) analyzed some caricatures in Iraqi TV Media. He aimed at studying selected media caricatures from Al-Baghdadia TV, drawn by Salim Al-Rubayee. He analyzed these caricatures based on Gricean Cooperative principle. It was found out that the caricatures observed all the maxims of quantity, relation and manner, except for the quality maxim. It was flouted intentionally for sarcastic reasons.

Bany Salameh (2015) analyzed Emad Hajjaj's caricatures of Abu Mhjoob, a well-known sarcastic character among Jordanians, in the light of the Cooperative Principle. The researcher examined thirty caricatures of Abu Mahjoob which flouted the Gricean maxims of quantity, quality, relation and manner in an attempt to answer three questions. The first two questions addressed the humorous mood which is created via the 30 caricatures of the study, and the most flouted maxims to create such mood. As for the third question, it attempted to find the role of both the verbal language as well as the visual elements in delivering the intended messages beyond these caricatures. The researcher divided her caricatures into sections (political, economic and social messages) according to the type of message they attempt to convey. The study also employed three types of context to deliver the implicature's meaning. These types are: background context, physical context and social context. This study found that Hajjaj flouted all the Gricean maxims in his caricatures to poke fun. The most flouted maxim was the maxim of relevance which contributed to the creation of fun. In order to make his messages easier for people to understand, Hajjaj used both visual elements and verbal language in presenting issues inside and outside Jordan between 2002 and 2015. 


\section{Findings and Discussion}

It was found that the maxim of quality was flouted the most, followed by the maxim of relation, the maxim of manner and the maxim of quantity in "Muatin hasb alttalab". Compared to other maxims, the maxim of quality was by far the most frequently flouted. This finding is far from being implausible since the main characters who flouted the maxims the most are afraid to speak up and voice their opinions. They tend to be mendacious in order to say what they think but implicitly. In this way, they not only convey their intended meaning, but also avoid taking responsibility for it. The maxim of relation was flouted very frequently as well (26.9\%). A possible explanation is that when you respond irrelevantly, you can attract people's attention and propel them to infer your intentions and thus arrive at a particular effect. The third flouted maxim was manner. The manner maxim states that interlocutors should 'Be perspicuous. (1) Avoid obscurity of expression. (2) Avoid ambiguity. (3) Be brief (avoid unnecessary prolixity). (4) Be orderly'. All of the previous requirements were flouted in the play due to unclear, ambiguous and lengthy statements. The maxim which was flouted the least in this play was the maxim of quantity. The reason behind the low percentage of flouting this maxim is that the play was written in a critical period of time in Jordan which required the utterances of the play to be sufficiently informative.

Similar to "Muatin hasb alttalab", the second play of this study "Al'an fahumtukum" flouted all the Gricean maxims. The most flouted maxim was relation (34\%). This maxim requires interlocutors to 'Be relevant' in their contributions. The results have revealed that the characters of the play, especially the main character "Abu Saqer", try to get their massages across through stating irrelevant contributions to the context or to the previous contribution. A possible reason is that the relation maxim is connected to all other maxims. Consequently, if you want to be relevant, you have to be truthful, informative and perspicuous. Being irrelevant forces interlocutors to look for a connection between the irrelevant implicature and the context to get the intended or implied message. Of course, getting the message is not difficult for interlocutors who share the same culture.

As for the quality maxim, it was flouted the most (32.8\%) in this play as was the case in "muatin hasb alttalab". This finding lends support to the view long held by Grice who recognizes the maxim of quality as having a unique status among the other conversational maxims (Grice 1989):

...it might be felt that the importance of at least the first maxim of Quality is such that it should not be included in a scheme of the kind I am constructing; other maxims come into operation on the assumption that this maxim is satisfied. ( p.27)

Next comes the manner maxim. Flouting this maxim helped the characters avoid being judgmental towards certain people or issues that are discussed in the plays. The last maxim is the quantity maxim. It was the least flouted in both plays due to the fact that the characters are discussing critical issues about Jordan and the Arab world which requires their conversations to be informative.

The second question of the study aimed at finding the possible functions that these flouts performed in both plays. "Muatin hasb alttalab" discussed many issues through flouting the Gricean maxims. The major purposes behind these flouts according to their frequencies were respectively: political, social/economic, social/political, economic/political and social. The biggest amounts of functions were political followed by social/economic functions. Naturally, vices such as corruption are held up to ridicule in satirical plays with the intent of shaming individuals, government or society itself into improvement. Thus, specific functions were observed by flouting the maxims: criticizing the government's decision to increase bread prices, questioning money sources and its unequal distribution, demonstrating how poverty blocks the right to freedom of speech, emphasizing the senators' dysfunctional role in the parliament, hinting at lack of democracy, expressing dissatisfaction with the government's decisions, fear to express one's opinions, fear of imprisonment and referring to torture in prisons indirectly.

Implicatures in "Al'an fahumtukum" were found to fulfill more various functions than "Muatin hasb alttalab". This difference relates to the fact that it also had more implicatures as well as more flouts due to the various issues it tackles. Similar to "muatin hasb alttalab", it served specific functions beyond the general functions. These functions, depending on their frequencies, were respectively: political, political/social, economic, social, economic/social and social/political/economic functions. Once again, the most frequent functions were political and social which is natural in satirical plays as mentioned before. Each implicature in the play flouted one or more of the Gricean maxims and served a certain purpose in return. 
These functions were: describing ministers as capable of being corrupt, judging the invalidity of the decisions of the members of the house of representatives in addition to judging their credibility, criticizing the forgery of elections, questioning the accuracy of poll results, accusing the government of stalling investigations into corrupt practices, stating that governments should be in prison instead of being in charge, criticizing the way Jordanians revolt against injustice, mocking the composition of the cabinet in Jordan and rewarding corrupted ministers instead of punishing them.

To sum up, the pragmatic functions of flouting Grice's maxims in the two plays helped the main characters take a noncommittal attitude towards what they are saying and thus avoid any sanctions that may follow from stating directly what they think of.

\section{Conclusion}

The present study sought to find out how often the conversational maxims were flouted in two Jordanian satirical plays "Muatin hasb alttalab" (1997) and "Al'an fahumtukum" (2012). The data was analyzed in light of the Cooperative Principle of Grice (1975). The study attempted to answer three main questions: what conversational maxims are flouted? Which ones are flouted the most in both of the plays? And what are the possible functions these flouts perform in the two plays? It was found that the most frequently flouted maxims in both plays were the quality and relation maxims. Moreover, the present study revealed that each instance of flouting in both of the plays had a certain function to perform. The maxim of quality, for example, was flouted repeatedly by the main characters of the two plays. They misrepresented their information in order to help the hearer understand the intended meanings of their utterances and avoid bad consequences at the same time. The maxim of relation was also flouted prudently by the main characters of the two plays by shifting the topic of discussion to imply fear of imprisonment and torture.

Table (1): Frequencies of flouting of conversational maxims in "Mutatin hasb Alttalab" and "Al'an fahumtukum"

\begin{tabular}{|l|l|l|}
\hline Maxims & $\begin{array}{l}\text { "Muatin } \\
\text { alttalab" percentages }\end{array}$ & "Al'an fahumtukum" percentages \\
\hline Quality & $34.6 \%$ & $32.8 \%$ \\
\hline Relation & $26.9 \%$ & $34 \%$ \\
\hline Manner & $25 \%$ & $23 \%$ \\
\hline Quantity & $13.5 \%$ & $10.2 \%$ \\
\hline
\end{tabular}

Table (2) Functions of flouts in "Muatin hasb alttalab"

\begin{tabular}{|l|l|}
\hline Function & Percentage \\
\hline Political & $66.6 \%$ \\
\hline Social/Economic & $18.9 \%$ \\
\hline Social/Political & $7.4 \%$ \\
\hline Economic/Political & $3.7 \%$ \\
\hline Social & $3.7 \%$ \\
\hline
\end{tabular}

Table (3) Functions of flouts in "Al'an fahumtukum"

\begin{tabular}{|l|l|}
\hline Function & Percentage \\
\hline Political & $43.6 \%$ \\
\hline Political/Social & $20.5 \%$ \\
\hline Economic & $18 \%$ \\
\hline Social & $7.7 \%$ \\
\hline Economic/Social & $5.1 \%$ \\
\hline Social/Political/Economic & $5.1 \%$ \\
\hline
\end{tabular}




\section{References}

Ahmed, M. F. (2007). On the relationship between Grice's maxims and humorous discourse. ADAB AlRAFIDAYN, 45, 49-66.

Bach, K. (1994). Semantic slack: What is said and more. In S.L. Tsohatzidis, (Ed.), Foundations of speech act theory: Philosophical and linguistic perspectives( pp.267-291). London: Routledge.

Bany Salameh, H. (2015). A pragmatic study of flouting Grice's maxims in Emad Hajjaj's caricatures of Abu Mahjoob. Retrieved from The Hashemite University. (Unpublished master's thesis).

Bouton, L.F. (1988). A cross-cultural study of ability to implicatures in English. World Englishes, 7, 183-196.

Davis, B. L. (2010). Grice's cooperative principle: meaning and rationality. Journal of Pragmatics, 39, $2308-2331$.

Devine, J. 1982. A question of universality: conversational principles and implicatures. In M. A. Clarke \& J. Handscomde (Eds.), TESOL (pp. 191-206). Washington DC: TESOL.

Ibrahim, R. (2014). A socio-pragmatic study of some caricatures in Iraqi TV. Media. Research on Humanities and Social Sciences, 4,165-176.

Cutting, J. (2002). Pragmatics and discourse: A resource book for students ( $2^{\text {nd }}$ ed.). New York: Routledge.

Grice, H. P. (1969). Vacuous names. In D. Davidson and J. Hintikka, (Eds.), Word and objections: Essays on the work of W.V. Quine (pp.118-145. Dordrecht: Reidel.

Grice, H. P. (1975). Logic and conversation. In P. Cole and J. L. Morgan, (Ed.), Syntax and Semantics 3: Speech Acts. New York: Academic Press.

Horn, L.R. (1984). Towards a new taxonomy of pragmatics inference: Q- and R-based implicatures. In D. Schifrin, (Ed.), Meaning, form, and use in context: Lingui applications (pp.11.42). Washington, DC: Georgetown University Press.

Horn, L.R. (2004). Implicature. In L. R. Horn \& G. Ward, (Eds.), The handbook of pragmatics (pp.3-28). Oxford: Blackwell.

Leech, G. (1983). Principles of politeness. London and New York: Longman.

Levinson, S. C. (1995). Presumptive meanings: The theory of generalized conversational implicature. Cambridge, MA: MIT press.

Paltridge, B. (2012). Discourse analysis: An introduction. London, Bloomsbury Academic.

Rost, Michael. (2011), Teaching and researching listening. [Online]Available: https://www.scribd.com/document/370037790/Applied-Linguistics-in-Action- Michael-Rost-Teachingand-Researching-Listening-Pearson-Education-ESL- 2011-pdf (October 20, 2018)

Sperber, D. and Wilson, D. (1995). Relevance: Communication and cognition.

Oxford: Blackwell.

Thomas, J. (1995). Meaning in interaction: An introduction to pragmatics. London: Longman.

Thomas, J. (2006). Cross-cultural pragmatic failure. Applied Linguistics, 4,91-112. 